\section{Post-control of agricultural subsidies provided by EU}

\author{
Kornélia Ficzere Nagymihály ${ }^{1}$ - László Czencz ${ }^{2}$ \\ ${ }^{1}$ Károly Róbert College, Faculty of Economics, Gyöngyös \\ ${ }^{2}$ Hungarian Customs and Finance Guard Central Control \\ Headquarters, Special Department, Budapest \\ kficzere@karolyrobert.hu
}

\section{SUMMARY}

The greatest part of the incomes (nearly fifty percent) of the European Union is spend on the agriculture and the agricultural policy is the most complex field among the common policies. In Hungary the payments from Guarantee Section of EAGGF are carried out by one Paying Agency (Agricultural and Rural Development Agency), the post audit of payments are carried out by Investigation Network of Hungarian Customs and Finance Guard on the base of Council Regulation No. 4045/89. A full cooperation of the business operators is expected during the audit, which means the presentation of the complete accounting file related to subsidies. To avoid declarations on irregularities during the audit and the following order on repayment of the subsidy, all requirements of gaining subsidies have to be kept. The state authorities, in present case the customs authority should pay special attention to the risk analysis activity, and its harmonising with the proposals and guidelines of the Commission. Getting acquainted and using in practice the actual requirements and proposals of the Commission's guidelines is expected at all levels of the control service of the HCFG, but primarily the Special Service has to continue its present practice in this field. The measures mentioned above, respectively the effective period taken under analysis teens from the date of accession until June 2005.

Keywords: payments from Guarantee Section of EAGGF, export-refund, special service, post audit of payments, risk analysis

\section{SIGNIFICANCE OF THE TOPIC}

Regulation No 4045/89 of the EEC on the post control of payments from the Guarantee Section of the European Agricultural Guidance and Guarantee Found (EAGGF), and the details of its execution is even among those relatively less known, who often study the rules related to the agriculture of the EU (the experts of the financial allocation system of the agricultural field). In this work we would like to give information on what this regulation aims; when, who and why does the audits, and what is expected from the audited parties, from the business operators themselves.

The growing number of business operators benefiting from the measures financed by this Guarantee Section certifies how current this topic is. You should know that the financing in question is granted by the European Union based on the measures of the agricultural policy to those beneficiaries who applied for it, if the Agricultural and Rural Development Agency (MVH) accepts the application and regards the conditions of the payment as appropriate.
Which are these measures? To sum up: all those, which do not fall under the Structural Funds! All those, which can be linked to the first pillar of the Common Agricultural Policy, e.g. market-, filed- and animal-based subsidies, as well as the financing of rural development (so called accompanying measures). (The main measure types appearing in Hungary will be named later!)

\section{PLACE OF PAYMENTS}

In Hungary the transfer of amounts is done by the Agricultural and Rural Development Agency (MVH), which is an accredited payment agency and also provides all other activities related to this, like considering applications, licensing, and pre-payment controls.

The beneficiaries presumably have correct information on these activities, respectively on the licensing procedure methods of the MVH, since the number of applicants has multiplied compared to last year, though the number of those paid among the titles that might be subsidized does not even reach hundred (Halmai, 2003). A great number of beneficiaries, however, do not have enough knowledge yet about what is happening after the payments, though in the near future some of them can expect post audit measures of the authorities.

\section{POST AUDIT AUTHORITIES OF THE PAYMENTS}

Government decision No 2041/2003 of the Hungarian government reckoned the post audit of the payments from the Guarantee Section of the EAGGF among the tasks of the Hungarian Customs and Finance Guard. During the EAGGF fiscal year that ended on the $15^{\text {th }}$ October 2005 the EU transferred more than 100 billion HUF to the accounts of the Hungarian beneficiaries, which amount was granted from the Guarantee Section.

A significant part of these amounts aggregate the amounts paid in form of field-based subsidies, which does not come under the ruling in question and does not constitute the tasks of the Hungarian Customs and Finance Guard. Before the post audit of the payments the MVH checks the general conditions of the entitlement, which are in the first line:

- agricultural growers farming on the territory of the EU, that are considered that by the member state,

- agricultural grower registered on the base of reg. 141/2003 of the Hungarian government, 
- who effectively uses (cultivates) the given land and bears the costs of farming and the risks of production,

- applies for subsidy (the application for fieldbased subsidies happens on an application-form!),

- all agricultural parcels have to be bigger than 0.3 hectare,

- the areas covered by one application have to be at least 1 hectare (in case of grape-fruit min. 0.3 hectare),

- only one application can be sent in on the same agricultural parcel in the same fiscal year under the same title,

- the case maps of the "Right Agricultural and Environmental Status, have to be kept.

From the $1^{\text {st }}$ May 2004 the Hungarian Customs and Finance Guard is the only proceeding authority in those post audit cases, which are laid in its jurisdiction by the regulations No $15 / 2004$ and No 23/2004 of the Ministry of Finance in consideration of the execution of regulation No 4045/89 (EEC) of the Council.

The HCFG established the Special Service obligatory assessed for all member states in a regulation for executing the tasks, which Service provides the supervision and co-ordination in point of the post audits related to the payments financed by the Guarantee Section of the EAGGF, for the sake of the entire execution of the EU-regulation in question.

Moreover, it prepares those reports and plans ordered by the regulation, which are expected by the Commission of the EU according to what is written in the regulations No 4045/89 (EEC), respectively its regulation for execution - No 4/2004 (EC). Most important among these are the risk analysis method, and the audit plan itself, which is a list of subsidyholder business operators selected in consideration of the content of the risk analysis method.

The Special Service mentioned before prepares a risk analysis method using the payment data of the $\mathrm{MVH}$ for the titles under the regulation, the number of which in Hungary does not reach hundred yet, but can be classified into the following important areas:

- export-refund sphere,

- intervention storage,

- vegetable and fruit-processing subsidies,

- the school-milk subsidy and

- other titles (e.g. for setting up and running Producers' Lobby, subsidy paid for bee-keepers ...) (Halmai, 2002).

During its work it uses all experiences and viewpoints that accumulated in the past years at the Commission, respectively at the control services of the single member states.

\section{CIRCUMSTANCES OF THE POST AUDIT FOLLOWING THE AVAILING OF EXPORT- REFUND}

Aim of the export-refund is a subsidy to equalize the higher community and lower world market prices to keep the world market competitiveness of the
European Union's (EU) exporters on the ground of compensating them in the form of refund after the delivery of agricultural products bought up at high prices from community producers.

Referring to the quantity units of the delivered products differing refund amounts can come up arising from the destination.

In point of the refund rate we differentiate to types of export-refunds. According to this the refund can be uniform or differentiated. In case of a uniform refund the refund rate is equal in point of all destinations. We call it differentiated refund, if in case of a certain third country or group of countries the European Commission quotes a refund rate differing from that of all other countries. The range of products coming in for refund and its rate is determined by the Commission of the EU, and published in the Official Journal of the European Community. The refund rate can change monthly, weekly or even daily depending on the regulations regarding the concerned sector. The determined refund rate can also change depending on the use or destination of the product (Europäische Kommission Generaldirektion Landwirtschaft: Zusammenfassender Bericht /22.04.2004/).

During the post audit the exporter has to present appropriate evidence to the auditor proving that he has fulfilled all requirements to gain the given export-refund amount (e.g. he has really delivered the goods to the country stated in the export licence, the delivered goods originate from the EU, and the deadline for delivery has not been exceeded, the products has been released into free circulation in the country of destination ...).

\section{POST AUDIT OF THE PAYMENTS FINANCED FROM THE GUARANTEE SECTION OF THE EAGGF ACCORDING TO REGULATION 4045/89 (EEC)}

Regulation No 4045/89/EEC on controls executed by member states on activities under the financing system of the Guarantee Section of the European Agricultural Guidance and Guarantee Fund and on the overruling of EEC guideline No 77/435, regulates primarily the selection of those affected by the audit, the execution of controls, the rights and obligations of the audited entity, as well as the content and size of the reports to be done to the Commission of the EU on the execution of the regulation.

Council regulation 4045/89 (EEC) defines the effective and regular execution of measures that constitute the direct or indirect part of financing system of the Guarantee Section of the EAGGF. According to the regulation the accounting documents of the beneficiary or the business operator obligated to pay have to be controlled, if these documents are in direct or indirect connection with the above mentioned measures.

It is the task of the member states to audit the accounting of the companies to be controlled. While doing so and during the selection of the companies to be controlled they have to care for the highest 
probability of securing the prevention and exploration of irregularities affecting the payments from the Guarantee Section of the EAGGF. During the selection - among others - the financial situation of the company in connection with this speciality and other risk factors should be taken into consideration (Europäische Gemeinschaften Rechnungshof Sonderbericht Nr. 3/2004).

Since it has came into effect, regulation 4045/89 (EEC) has altered several times, the value limit for the selection of business operators has been raised several times. At the moment 150 thousand Euros are the limit for the business operators to get into the audit plan. According to the regulation the range of beneficiaries who will be selected for audit is about half of the number of business operators reaching the 150 thousand Euro limit. When using the risk analysis method some operators that does not even reach a subsidy amount of 50 thousand Euros in the given year also get into the range of selected, while other business operators, who bring more than 150 thousand Euros of subsidy to book in the EAGGF fiscal year might drop out of it. The number of audits to be executed in the given audit period or fiscal year is equal to half of the number of entities reaching the value limit. Because of the speciality of the EAGGF fiscal year the audit period does not start with the first day of the year neither, but on $1^{\text {st }}$ of July.

As mentioned before, according to the regulation in question the post-control is primarily of administrative nature. It means the control of the accounting files of the company, the business operator taken under audit, respectively control. It contains all kinds of accounting audit, in case of which this kind of audit seems to be effective, and which does not belong to controls that are defined by the IACS (Integrated Administration and Control System) regulation 3508/92 (EEC).

It has to be mentioned here, that there are such measures that are excluded from regulation 4045/89, though they belong to the financing of the Guarantee Section of the EAGGF. These have been excluded by the Commission according to paragraph (4) of article 1 of regulation No 4045/89 because in these cases the payment procedures are inappropriate by their nature for being object of post controls based on the audit of commercial documents. Regulation No 2311/2000 (EC) excludes the measures and projects aiming agricultural development that are nut under the rule of regulation No 4045/89 (EEC) from this range of the post controls.

The domestic handling of school milk subsidies is worth to be mentioned if we pan out about the details of post controls, as well as the accounting filing and the special solution of post controls that result from it. Differing from other member states the application for school milk subsidies in our country is not the competence of the educational institutes, but that of their maintainer, the local government, in some cases foundations. (A further domestic speciality is that though regulation 2707/2000 (EC) defines 0.251 as the daily quantity of school milk per student that can be subsidized, but the domestic packaging- production only allowed 0.2 litre-packs. Thus the students got some less subsidized milk).

Based on the regulation in question it is the responsibility of the school, respectively kindergarten maintainers, to keep records in which he indicates the producers or the suppliers of the products, the name and address of the educational institutions, as well as the quantity sold or provided for them. Accordingly this is the record that has to be controlled during the post control of this subsidy at the maintainer of the given institution.

The Commission lays a great emphasize on the execution of the regulation. The controlling services affected meet annually on a conference where they discuss practical questions on the adaptation of the regulation and evaluate the typical irregularities reckoned.

\section{OPINION OF THE EU ON THE POST- CONTROL OF SUBSIDIES FINANCED FROM THE GUARANTEE SECTION OF THE EAGGF}

Towards the effective functioning of the EAGGF subsidy system the EU defines the member state control of the orderly use of subsidies as a requirement. The member states practice their control activities on one hand with the controls built in the payment procedure, on the other hand with the on site post controls. The EU evaluates these control mechanisms through its Commission within the framework of its supervising control activity.

The post controls in connection with the payments financed from the Guarantee Section of the EAGGF are the core of all controls connected to the EAGGF inasmuch as these controls can be executed in all cases on site at the beneficiary up to three years back in the past. Aim of the control is the on site supervision of orderly use of the use of subsidies and the elimination of irregularities detected.

If the post control detects irregularity, the paying agency of the member state, in this case the MVH is obliged to claim back and pay back the amount used irregularly to the EU budget, based on the record placed during the post control. In such case the budget of the member state is not charged extra costs, since the member state collects back the amount of subsidy it has to pay back to the EU from the controlled company. If the irregularity is detected by any organisation of the EU Commission during a supervisory control activity after the post control, the Commission might exercise its mentioned right of sanctioning beyond the concrete detected deficiency, depending on its consideration (The European Commission: Guidelines for the calculation of financial consequences when preparing the decision regarding the clearance of the accounts of EAGGF Guarantee Section). (On one hand payments from the budget has to be performed to the Commission the collection of which is not secured within the member state, on the other hand the sum of the subsidies of next year - as a further sanction - might be reduced by the Commission by $2-100 \%$. In point of some member states there have been some examples for this.) 
TASKS OF THE HUNGARIAN CUSTOMS AND FINANCE GUARD DURING THE EAGGF POST-CONTROLS

The payments from the Guarantee Section of the EAGGF might happen due to several titles like internal market interventions (storage in, storage out subsidy, guidance bonuses, levy, compensation subsidies), export subsidy and other (veterinary and plant health subsidy, direct producer subsidy, environmental subsidy, etc.). The variegation of these titles and the strict expectations made for the payments indicate the difficulty, the weight of this task. The post control system is handled emphasised within the $\mathrm{EU}$, therefore the whole range effective running of post controls connected to the EAGGF is also very important.

These expectations have been fulfilled by the Hungarian Customs and Finance Guard by setting up the Special Service mentioned before and fitted its net providing "classic" company control tasks for the execution of the new post controls according to EAGGF, respectively regulation $4045 / 89$.

The control net is located at the midlevel of the organisation structure of the Hungarian Customs and Finance Guard. The Special Service supervising and controlling the audits according to regulation 4045/89 (EEC) has been set up within the organisation unit of the Central Control Headquarter, the control over which has the Customs Directorate of the HCFG, in turn the Audit Departments executing the post controls under the supervision of the Special Service have been set at the Regional Headquarters.

\section{ACTIVITIES OF THE DOMESTIC SPECIAL SERVICE}

According to article 11 of regulation 4045/89/EEC all member states have to set up a so called special department/service that has competence on:

- execution of controls indicated in the regulation, by officers that belong directly to the special service,

- or the coordination of controls that are executed by officers of other offices, in supervision of the regulation.

Based on the decision of the Hungarian Customs and Finance Guard (HCFG) the Special Service (hereafter: SS) has been set up in the Central Control Headquarter belonging to the supervision of the Customs Directorate of the Hungarian Customs and Finance Guard.

\section{TASKS OF THE SPECIAL SERVICE}

The Special Service and the departments executing the post controls are independent from the organisation taking part in the payments (MVH). The controlling net covers the whole territory of the country.

The tasks of the SS are very diverse. It has nine different quarterly, annual and casual reporting obligations. It keeps contact to the European
Commission, with the OLAF, with the Special Services of the other member states and with the MVH. It initiates and executes cross-checks at the member states, hosts and sends auditors from and to associated services, if required. It takes part in simultaneous controls affecting several member states co-ordinated by the Commission.

As this is a pretty special field, regulation $4045 / 89$ expressly ordered also the risk analysis into the competency of SS in case of payments from the Guarantee Section of EAGGF. A seeded task of the Special Service is to execute the post controls defined in regulation 4045/89/EEC and the linked preparatory and coordination activities (The European Commission: Post Control Packages 7DE/06/94/68770201.P00 (EN) Re/re).

During the post controls the auditors have to proceed with due diligence and it is important that the control of this is secured. This obligation necessitates the development of adequate processes for planning, executing and monitoring the work.

The Special Service furthers the work-out and documentation of methods made for planning the on site controls requiring documentation and licensing.

\section{PRELIMINARY ANALYSIS OF THE INCREASED SUBSIDIES PAID IN THE EAGGF FISCAL YEAR 2004/2005}

In July 2005, for example, the auditors of the department DG AGRI J2 of the Commission of the European Union attracted the attention of the Special Service while executing a control in Hungary on the fact, that the Commission, respectively the DG AGRI pays special attention to the trade of agricultural products. In this regard the execution of regulations $230 / 2004 / \mathrm{EC}$ and $735 / 2004 / \mathrm{EC}$ that came into force in consequence of the accession of the Czech Republic, Estonia, Cyprus, Latvia, Lithuania, Hungary, Malta, Poland, Slovenia and Slovakia and their amending regulations on the transition measures is controlled continually.

Though the compliance with the contents of the regulation mentioned has to be controlled primarily by the paying agency, in Hungary by the MVH, the responsibility of the Special Services is great as well in clearing up the speculative inventory accumulations respectively in avoiding repeated application for subsidies for products that have already received export subsidy.

\section{ACTUAL POINTS OF RISK ANALYSIS}

During the preparation of controls the experiences of the EU member states mentioned before have to be taken into consideration, primarily in the field of risk analysis. While a rise in the amount of exported pork meat to an Islamic country might be a obvious sign of certain irregularities, possibly of a re-export differing from the sending country, the rising import of any by-products of starch production to Hungary to an extent experienced never before from some "older" member states, in contrast, might indicate problems of a totally different nature in the field of risk analysis. 


\section{REFERENCES}

Halmai, P. (szerk.) (2003): Az EU Közös Agrárpolitika, (Fogalomtár) Agroinform, Budapest

Halmai, P. (szerk.) (2002): Az Európai Unió agrárrendszere. Mezőgazda Könyvkiadó, Budapest

Europäische Gemeinschaften Rechnungshof Sonderbericht Nr. $3 / 2004$
Europäische Kommission Generaldirektion Landwirtschaft: Zusammenfassender Bericht /22.04.2004/

The European Commission: Guidelines for the calculation of financial consequences when preparing the decision regarding the clearance of the accounts of EAGGF Guarantee Section

The European Commission: Post Control Packages 7DE/06/94/68770201.P00 (EN) Re/re 